\title{
ASPEK KESELAMATAN DAN KENYAMANAN YANG PERLU DIPERHATIKAN OLEH ENTERPRENEUR DALAM PEMBUATAN AGRO WISATA BERBASIS WISATA PETERNAKAN
}

\author{
Dian Akbar Muntaha ${ }^{1}$, Dadang Suganda ${ }^{2}$, M Sapari Hadian ${ }^{3}$ \\ ${ }^{1}$ Sekolah Pascasarja, Universitas Padjadjaran, Jalan Dipatiukur no.53 Kecamatan Coblong Kota Bandung \\ ${ }^{2}$ Fakultas Ilmu Budaya, Universitas Padjadjaran, Jl. Raya Bandung Sumedang KM.21, Sumedang \\ ${ }^{3}$ Magister Pariwisata Berkelanjutan, Sekolah Pascasarjana Universitas Padjadjaran, Jl. Dipatiukur No.35 Bandung \\ E-mail:dian15015@mail.unpad.ac.id, dadang.suganda@unpad.ac.id, sapari@unpad.ac.id
}

\begin{abstract}
ABSTRAK
Sektor peternakan merupakan industri yang berperan untuk memproduksi hasil ternak untuk ketahanan pangan masyarakat. peternakan secara umum adalah aktivitas produksi produk peternakan mulai dari hulu hingga hilir yang bersifat kompleks dan terstruktur. Menurunnya jumlah peternak mandiri menunjukkan hilangnya kondusivitas ranah usaha yang menunjang peternak rakyat, karena sarana produksi peternakan ketergantungan pihak lain akibat lemahnya modal dan lemahnya akses peternak terhadap sumberdaya peternakan. usaha peternakan skala mandiri sudah mulai kehilangan nilai ekonomi. Oleh karena itu perlu adanya upaya atas masalah ini. Salah satu yang bisa dilakukan adalah merubah aktivitas peternakan yang semula adalah produksi hasil ternak menjadi aktivitas pariwisata. Sebagai enterpneur yang akan membuat tempat agrowisata perlu menganalisis aspek - aspek peternakan berupa teori maupun teknis demi kepuasan wisatawan dalam berwisata agrowisata. Setidaknya pada suatu kawasan agrowisata sudah menyiapkan tindakan preverentif apabila terjadi hal yang tidak diinginkan dan menimbulkan kerugian. Aspek keselamatan dan kenyamanan wistawan merupakan hal yang mutlak diperhatikan dalam pembuatan tempat wisata agrowisata karena menyangkut dampak negatif yang mungkin terjadi dan menimbulkan kerugian apabila diabaikan. Selain sebagai tindakan preverentif, mempehatikan aspek keselamatan dan kenyamanan wisatawan juga secara tidak langsung memberi dampak yang positif bagi peternakan dan hewan ternak itu sendiri.
\end{abstract}

Kata kunci; Peternakan, Agrowisata, Keselamatan dan Kenyamanan.

\section{SAFETY AND CONVENIENCE ASPECTS THAT NEED TO BE CONSIDERED BY ENTREPRENEUR IN MAKING AGRO-TOURISM BASED ON LIVESTOCK TOURISM}

\section{ABSTRACT}

The livestock sector is an industry whose role is to produce livestock products for community food security. animal husbandry in general is the activity of producing livestock products ranging from upstream to downstream which is complex and structured. The decrease in the number of independent breeders shows the loss of conducivity of the business domain that supports smallholder farmers, due to the dependency of other livestock production facilities due to weak capital and weak farmers' access to livestock resources. independent scale animal husbandry businesses have begun to lose economic value. Therefore there needs to be an effort to overcome this problem. One thing that can be done is to change livestock activity which was originally a livestock production into tourism activities. As entrepreneurs who will make agrotourism sites need to analyze aspects of animal husbandry in the form of theories and techniques for the satisfaction of tourists in agro-tourism. At least in an agro-tourism area, it has prepared pre-incentive measures if something unexpected happens and causes losses. Aspects of the safety and comfort of tourists is an absolute concern in making agro-tourism attractions because it involves negative impacts that may occur and cause harm if ignored. Aside from being a preverentive measure, paying attention to the safety and comfort aspects of tourists also indirectly has a positive impact on livestock and livestock themselves.

Key words; Animal Husbandry, Agrotourism, Safety and Comfort. 


\section{PENDAHULUAN}

Sektor peternakan merupakan industri yang berperan untuk memproduksi hasil ternak untuk ketahanan pangan masyarakat. peternakan secara umum adalah aktivitas produksi produk peternakan mulai dari hulu hingga hilir yang bersifat kompleks dan terstruktur. Sejatinya aktivitas peternakan dari sektor hulu adalah terjalinnya hubungan yang baik antara peternak dan hewan ternak yang dipelihara. Hasil produksi akan tinggi apabila hewan ternak dalam kondisi yang sehat dan prima. Sementara dari sektor hilir adalah bagimana terjalinnya hubungan yang baik antara peternak dengan target pasar dalam artian penjual produk ternak.

Peternakan terbagi menjadi 2 yaitu peternakan skala industri dan peternakan skala mandiri. Peternakan mandiri yaitu peternakan yang dimiliki oleh suatu koporasi sementara peternakan mandiri adalah peternakan yang dimiliki dan di kelola oleh sendiri, akhir - akhir ini pelaku usaha peternakan mandiri terus menurun. Menurut Sulaeman dkk, (2019) Menurunnya jumlah peternak mandiri menunjukkan hilangnya kondusivitas ranah usaha yang menunjang peternak rakyat, karena sarana produksi peternakan ketergantunganpihak lain akibat lemahnya modal dan lemahnya akses peternak terhadap sumberdaya peternakan. Kelemahan semacam ini terkait dengan adanya eksklusi sosial. Dilanjutkan bahwa Eksklusi sosial diartikan sebagai adanya kebijakan sengaja atau tidak sengaja berupa tindakan baik dari pemerintah maupun agen lainnya yang mengeksklusi sekelompok orang dari sebuah kesempatan, sehingga terputusnya akses dari sebuah kesempatan. Dampak eksklusi sosial melalui kebijakan regulasi tatakelola usaha peternakan baik rakyat maupun perusahaan besar, secara faktual telah mematikan usaha peternakan rakyat mandiri.

Berdasarkan kajian diatas menunjukan bahwa usaha peternakan skala mandiri sudah mulai kehilangan nilai ekonomi. Oleh karena itu perlu adanya upaya atas masalah ini. Salah satu yang bisa dilakukan adalah merubah aktivitas peternakan yang semula adalah produksi hasil ternak menjadi aktivitas pariwisata. Menurut Rohman dan Azizah (2019) bahwa Peluang sektor pariwisata cukup prospektif, karena selain sebagai salah satu penghasil pertumbuhan ekonomi pariwisata sektor pariwisata diharapkan dapat berpeluang untuk dapat menjadi pendorong pertumbuhan sektor pembangunan lainnya, seperti sektor perkebunan, pertanian, perdagangan, perindustrian dan lain-lain. Salah satu unsur dari sektor pertanian yang saat ini belum tergarap secara optimal adalah agro wisata (agro tourism). Tujuan dari agrowisata peternakan itu sendiri adalah bagaimana masyarakat mengetahui aktivitas peternakan dari hulu hingga hilir. Artikel ini akan membahas aspek - aspek apa saja yang perlu diperhatikan seorang enterpreneur dalam mengubah peternakan menjadi agro wisata.

\section{METODE}

Artikel ini menggunakan metode studi literatur di mana penulis membaca, mencatat, dan mengolah bahan dari sumber pustaka, media massa, dan penelitian terkini. Metode ini pun membantu menemukan pemecahan masalah dari hal yang ditemukan di lapangan.

\section{HASIL DAN PEMBAHASAN}

Agrowisata peternakan sebenarnya sudah mulai banyak dikembangkan sebagai upaya memaksimalkan potensi peternakan di suatu daerah. Sudah mulai banyak penelitian untuk merubah aktivitas peternakan menjadi aktivitas agro wisata. Namun yang harus digarisbawahi adalah akan adanya interaksi antara wisatawan dengan hewan ternak yang bersifat hidup dan mempunyai perasaan. Hewan ternak yang menjadi atraksi wisata dapat membawa nilai positif dan benefit tetapi juga membawa nilai negatif berupa bahaya keselamatan wisatawan.

Sebagai enterpneur yang akan membuat tempat agrowisata perlu menganalisis aspek aspek peternakan berupa teori maupun teknis demi kepuasan wisatawan dalam berwisata agrowisata. Setidaknya pada suatu kawasan agrowisata sudah menyiapkan tindakan preverentif apabila terjadi hal yang tidak diinginkan dan menimbulkan kerugian.

(1) Secara teori, peternakan adalah sebuah aktivitas terstruktur antara peternak dengan hewan ternak. Peternakan bersifat tertutup dengan masyarakat diluar peternakan karena secara naluriah sifat hewan ternak sangat sensitif terhadap perubahan kondisi termasuk kehadiran orang asing sehingga pada situasi tertentu hewan ternak tidak merasa nyaman dengan kehadiran wisatawan.

(2) Pada suatu peternakan sangat disarankan untuk menerapkan sistem biosecurity. Satyanarayana dkk. (2008) menyatakan bahwa biosecurity berfokus pada menjaga kesehatan hewan dan mencegah masuknya patogen penyakit terbaru dengan menilai semua pencapaian pencapaian untuk kesehatan hewan. Penerapan biosecurity merupakan upaya untuk melindungi kesehatan hewan ternak dari penyakit patogen yang mungkin dibawa oleh orang yang masuk ke dalam peternakan misalnya wisatawan. Pedoman biosecurity mengacu pada peraturan dirjen 
peternakan dapat berbeda sesuai dengan jenis hewan ternak. Inti dari konsep biosecurity adalah bagaimana sebuah peernakan dapat terjaga sanitasi dan kebersihannya yang merujuk pada kesehatan dan kenyamanan wisatawan.

(3) peternakan tidak bisa di pisahkan dengan limbah. Olhe karena itu penting untuk menerapkan sanitasi limbah peternakan. Limbah peternakan bukan hanya limbah kotoran sisa pencernaan ternak tetapi limbah pakan dan limbah bekas air mandi juga perlu diperhatikan. Selain itu, dengan merubah kawasan peternakan menjadi agrowista maka beban limbah yang harus diolah menjadi lebih banyak dan kompleks. Solusi yang uumum untuk penanganan limbah peternakan adalah mengolahnya, misalnya dengan dibuat sebagai bahan bakar biogas. Akan tetapi tidak semua limbah dapat diolah oleh karena itu penting untuk seorang enterpreneur untuk mempelajari konsep pengolahan limbah yang terpadu mengacu pada konsep AMDAL (analisis dampak lingkungan) dan IPAL (instalasi pengolahan air limbah)

\section{SIMPULAN}

Aspek keselamatan dan kenyamanan wistawan merupakan hal yang mutlak diperhatikan dalam pembuatan tempat wisata agrowisata karena menyangkut dampak negatif yang mungkin terjadi dan menimbulkan kerugian apabila diabaikan. Selain sebagai tindakan preverentif, mempehatikan aspek keselamatan dan kenyamanan wisatawan juga secara tidak langsung memberi dampak yang positif bagi peternakan dan hewan ternak itu sendiri.

\section{DAFTAR PUSTAKA}

Rohman, T. R., \& Azizah, S. (2019). Strategi Pengembangan Wisata Edukasi Peternakan Di Kampung Susu Dinasty Desa Sidem Kecamatan Gondang Kabupaten Tulungagung Jawa Timur. Karta Rahardja: Jurnal Pembangunan dan Inovasi, 1(2), 6571.

Sulaeman, M., Mauludin, A., Sulistyati, M., Nurlina,L., Yunasaf, U., \& Alim, S. (2019). Dampak Eksklusi Sosial dan Model Pemberdayaan Peternak. Jurnal Sosial Bisnis Peternakan, 1(1), 19-30.

Satyanaraya, S.K.V.IAS., M. N. Reddy., Balasubramani., P. Chandrashekara., K.H.Rao and B.S. Santakki. 2008. SustainableLivestock Development. National Instituteof Agricultural Extension Management (MANAGE)

Andhira Pradesh, India. 